気管支喘息患者と慢性肺気腫患者の気道過敏性に対する 3 種の

ヒスタミン吸入試験測定值の比較

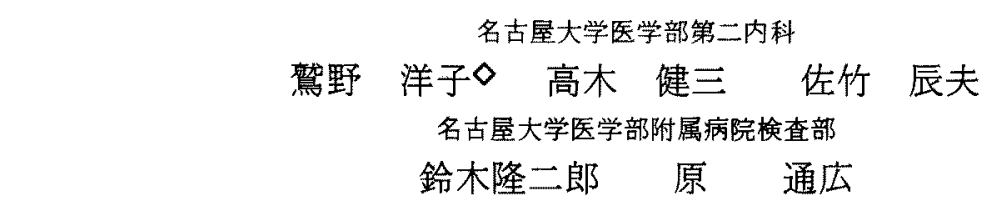

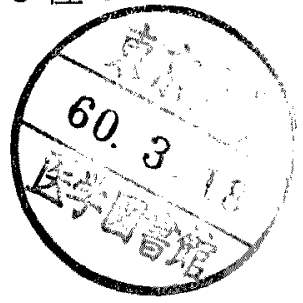

\title{
COMPARISON OF AIRWAY RESPONSIVENESS TO INHALED HISTAMINE WITH THREE METHODS IN PATIENTS \\ WITH BRONCHIAL ASTHMA AND CHRONIC PULMONARY EMPHYSEMA
}

Yoko Washino, MD, Kenzo TAKagi, MD and Tatsuo Satake, MD

The Second Department of Internal Medicine, Nagoya

University, School of Medicine, Nagoya

Ryujiro SUzUKI, MD and Michihiro HARA, MD

The Laboratory of the Nagoya University Hospital

\begin{abstract}
概要 気管支喘息患者に対する種々のヒスタミン吸入試験のうち，三つの方法を，同一患者に

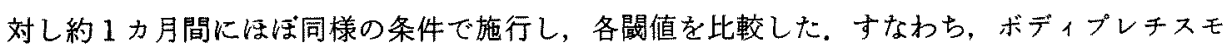
ダラフでspecific airway conductance (SGaw) を測定し，SGawが基準值の35\%減少したヒス タミン濃度をヒスタミン閾值（ $\mathrm{PC}_{35}$-SGaw）とし(body box法)，これを 1 秒量の $20 \%$ 低下し たヒスタミン濃度 $\left(\mathrm{PC}_{20}-\mathrm{FEV}_{1.0}\right)$, 拉よびアストグラフで測定した呼吸インピーダンスが上昇 する時点のヒスタミン濃度 (Cmin) と比較したわけである。な扔, 濃度は常用対数で示した。 気管支喘息患者の20例で, $\mathrm{PC}_{35}-\mathrm{SGaw}=1.70 \pm 0.11, \mathrm{PC}_{20}-\mathrm{FEV}_{1.0}=2.03 \pm 0.09, \mathrm{Cmin}=2.30 \pm$

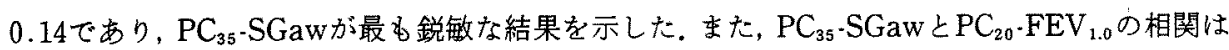
$\mathrm{r}=0.70$ の正相関を示した。, ょつて $\mathrm{PC}_{20}-\mathrm{FEV}_{1.0}$ は， $\mathrm{PC}_{35}-\mathrm{SGaw}$ 同様, 気道過敏性の指標とし て有用なことが証明された。ささらに，気管支喘息を合併していない慢性肺気腫患者の10例にも 同様の 3 法施行した。 その結果, $\mathrm{PC}_{35}-\mathrm{SGaw}=1.81 \pm 0.21, \mathrm{PC}_{20}-\mathrm{FEV}_{1.0}=2.29 \pm 0.34$, $\mathrm{Cmin}=2.77 \pm 0.21$ といずれも低い閥值を示した。次に, 横軸にヒスタミン濃度(対数表示), 縦 軸に\%SGaw（ヒスタミン吸入前SGawに対する割合の\%表示）をとり，この直線の傾きの絶対 值を reactivity とし，一方 $\mathrm{PC}_{35}$-SGawを sensitivityとすると，気管支喘息患者23例ではsen-

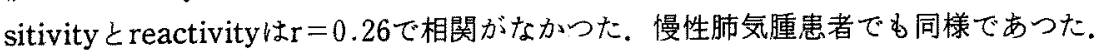

\section{I. 緒 言}

気管支喘息は, 気道過敏性と可逆性の気道狭窄 によつて特徴づられている。「気道過敏性」は， 一般的には，種々の刺激に対して気道の狭窄が招

[昭和59年 7 月17日受稿]
こりやすい状態を表わし，定量的には一定の気管 支收縮を惹起するのに必要な薬物量の閾値で示さ れる。ここ十数年来, 気管支喘息の診断々病態の 解明を目的として，気道過敏性を調べる種々の吸 入試験が施行されてきた。我々は，今回，ヒスタ ミン吸入後, ボディプレチスモグラフで, 気道抵 
抗之機能的残気量を測定し, 気道抵抗の逆数を残 気量で除したspecific airway conductance (以下. SGaw)を測定し，なた，SGawが基準値の35\%低 下したヒスタミン濃度をヒスタミン閾値（以下. $\mathrm{PC}_{35}$-SGaw) とした (以下, body box法).ささら に，1秒量の $20 \%$ 低下を指標とする，ヒスタミン 吸入試験の標準法)(以下，スパイログラフィー 法)，拉よび呼吸インピーダンスの上昇を指標とす るアストグラフによる検查法")(以下，アストグラ フ法）を施行した。本論文では，以上 3 種の吸入 試験を同一の気管支喘息患者に施行してそれぞれ の閶値を比較し，臨床的意義を検討した。

第 2 に，慢性肺気腫患者についても上記 3 法を 施行し, 気道過敏性の有無を検討した。

第 3 K, body box 法による個々の dose-response curveを, 横軸にヒスタミン対数濃度, 縦軸 に\%SGawをとり，最小二乗法による一次回帰式 によつてあらおし，この直線の傾きの絶対值を reactivity, $\mathrm{PC}_{35} \mathrm{SGaw}$ sensitivityとし, sensitivity と reactivityの相関の有無についても検討 した.

\section{II. 万 法}

\section{1) 対象}

慢性肺気腫を合併しない気管支喘息患者23名, 気管支喘息を合併しない慢性肺気腫患者12名を対 象として, 各症例について 1 力月以内に 3 種の吸 入試験を施行した。なお，検査時には呼吸困難な く，喘鳴を聴取しないことを原則とした。検査前， ステロイド薬（経口，注射）は24時間，抗ヒスタ ミン剂は24時間, 他の薬物は12時間の投薬をそれ ぞれ中止した。両疾患の診断は原則としてAmerican Thoracic Society ${ }^{3)}$ (1962) の定義に基づい たが，これに加えて選択的 4 倍拡大肺胞気管支造 影所見による形態学的変化も重視した。

\section{2）吸入綝物，希釈系列}

2 塩酸ヒスタミンを用いた。生理食塩水にて 倍々希橎した。濃度系列は以下の 10 系列とした。 $10000,5000,2500,1250,625,313,156,78$, $39,20 \mu \mathrm{g} / \mathrm{ml}$.

3）吸入方法
Body box法とスパイログラフィー法は, 圧搾空 気 $5 \mathrm{l} / \mathrm{min}$ でDevilbiss Model 646 Nebulizerを用 い,ノーズクリップを装着し安静換気で 2 分間吸 入させた。アストグラフ法にはBird Nebulizerが 設置されて和り王搾空気 $5 \mathrm{l} / \mathrm{min}$ である. 各濃度 1 分間ずつノーズクリップを装着し安静換気にて連 続吸入させた。

\section{4) 測定法と解析}

\section{(1) Body box法}

SRL（米国）社製Auto Box M-800を使用した。 患者を箱内に入れ (坐位), 肺気量変化分 $\left(\Delta \mathrm{V}_{\mathrm{L}}\right)$ 対時間曲線が安定し，熱的ドリフトが無視できる 時点で，患者に2Hzのpantingを指示し，気道抵抗 (Raw)，機能的残気量 (FRC) を測定した。 Raw は，原則として4ループ, FRCは 5 ループの平均 值をとつた。なお，患者には測定中はノーズクリッ プを装着させた。

はじめに, 機能的残気量 (Initial FRC), 気道抵 抗 (Initial Raw), SGaw (Initial SGaw) を測定 した. 生理食塩水を 2 分間吸入し, SGawが20\%以 上低下していない例では検査を続行した，20\%以 上低下していれば，5分後に，同様に生理食塩水 吸入を行ない，なお20\%以上のSGawの低下があ れば検査を中止した。

次に低濃度のヒスタミンから 2 分間吸入し直後 にFRC, Raw, SGawを測定した。 以下の解析のた めに必要な濃度まで，吸入，測定をくり返した。 すなわち，個々のdose-response curveを求めるた め, 緃軸に吸入前のSGawに対する\%をとり，横軸 にヒスタミン濃度をとり, 正確を期して最小二乗 法により一次回帰式を求めた。 Initial SGawを $35 \%$ 減少させるヒスタミン濃度を閾値 $\left(\mathrm{PC}_{35}\right.$. SGaw)とした。これ こensitivityとし, 一次回帰 式の傾きの絶対值をreactivityとした。な括, $\mathrm{PC}_{35}$. $\mathrm{SGaw} \mu \mathrm{g} / \mathrm{ml}$ 濃度の常用対数で示した。

（2）スパイログラフィー法

ヒスタミン吸入試験の標準法りに準じて行なつ た. 吸入前に 1 秒量を測定し基準値とした。生理 食塩水を 2 分間吸入後, 1 秒量を測定し，基準值 より10\%以上減少していない例では検査を続行し 
た. $10 \%$ 以上減少した例では， 5 分後に同様の生 理食塩水吸入を行ない，な拈10\%以上の1秒量の 減少があれば，検查を中止した。最低濃度のとス タミンから 2 分間吸入し, 直後に 1 秒量を測定し た. 順次濃度をあげていき，基準 1 秒量の20\%以 上低下すれば検査を中止した。

Dose-response curveを求めるため, 縦軸に吸入 前の 1 秒量に対する\%をとり，横軸に対数表示の ヒスタミン濃度をとり，正確を期して最小二乗法 により一次回帰式を求めた。この直線より，基準 值から 20\%低下するヒスタミン濃度を求め, 閾值 $\left(\mathrm{PC}_{20}-\mathrm{FEV}_{1.0}\right)$ とした。 $\mathrm{PC}_{20}-\mathrm{FEV}_{1.0}$ は $\mu \mathrm{g} / \mathrm{ml}$ の濃 度の常用対数で示した。

（3）アストグラフ法

アストグラフは，Chest社（日本）製TCK 6100 Hを使用した。生理食塩水に続き，各濃度のヒスタ ミン液を, 低濃度より 1 分每に連続的に安静呼吸 下で吸入させた。オッシレーション法 (3Hz固定) に上る呼吸インピーダンスを連続的に記録し，呼 吸インピーダンスが上昇し始める時点のヒスタミ ン濃度を閥値 (Cmin) とした。Cminは， $\mu \mathrm{g} / \mathrm{ml}$ 濃度值の常用対数で示した。

\section{III. 結 果}

気管支喘息群，慢性肺気腫群における，3法の sensitivityの平均值をTable 1に示した. 気管支喘 息群のうち，三つの方法とも成績がそろつた20例 での，各法による sensitivityの平均値は， $\mathrm{PC}_{35}$ $\mathrm{SGaW}=1.70 \pm 0.11, \quad \mathrm{PC}_{20}-\mathrm{FEV}_{1.0}=2.03 \pm 0.09$, $\mathrm{Cmin}=2.30 \pm 0.14$ となつている.両疾患群とも, body box法による $\mathrm{PC}_{35}$-SGawが最も低い值をと つており，次に $\mathrm{PC}_{20}-\mathrm{FEV}_{1.0}$ (スパイログラフィー 法), $\mathrm{Cmin}$ (アストグラフ法)の順となつている。 また，それぞれの平均值は，両疾患群間で有意差 はなかつた。

次に，気管支喘息群で，同一患者におけるbody box法での $\mathrm{PC}_{35}-\mathrm{SGaw}$ ，スパイログラフィー法 の $\mathrm{PC}_{20} \cdot \mathrm{FEV}_{1.0}$ ，およびアストグラフ法のC $\min の$ 関係をFig 1, Fig 2, Fig 3に示した。各図とも対 数目盛となつている．2方法間の相関をしらべる ため，最小二乗法により一次回帰式をるとめた。
Table 1. Comparison of $\mathrm{PC}_{20} \cdot \mathrm{FEV}_{1.0}, \mathrm{PC}_{35}$. SGaw and $\mathrm{Cmin}$ in bronchial asthma and chronic pulmonary emphysema. There is no significant difference of each mean value between the two disorders. $\mathrm{PC}_{35}$-SGaw is the most sensitive parameter among the three parameters. $\mathrm{PC}_{35} \cdot \mathrm{SGaw}$ : histamine concentration that produces a $35 \%$ reduction in specific airway conductance. $\mathrm{PC}_{20}$. $\mathrm{FEV}_{1.0}$ : histamine concentration that produces a $20 \%$ reduction in the second forced expired volume. Cmin: histamine concentration at the inflection point when the respiratory impedance increases.

\begin{tabular}{|c|c|c|c|}
\hline & $\begin{array}{c}\text { bronchial } \\
\text { asthma }\end{array}$ & $\begin{array}{c}\text { chronic } \\
\text { pulmonary } \\
\text { emphysema }\end{array}$ & $\mathrm{p}$ \\
\hline PC20-FEV/10 & $\begin{array}{c}2.03 \pm 0.09 \\
n=20\end{array}$ & $\begin{aligned} 2.29 & \pm 0.34 \\
n & =10\end{aligned}$ & NS \\
\hline $\mathrm{PC}_{35}$ SGaW & $\begin{array}{c}1.70 \pm 0.11 \\
n=20\end{array}$ & $\begin{array}{c}1.81 \pm 0.21 \\
n=10\end{array}$ & NS \\
\hline Cmin & $\begin{aligned} 2.30 & \pm 0.14 \\
n & =20\end{aligned}$ & $\begin{aligned} 2.77 & \pm 0.21 \\
n & =10\end{aligned}$ & NS \\
\hline
\end{tabular}

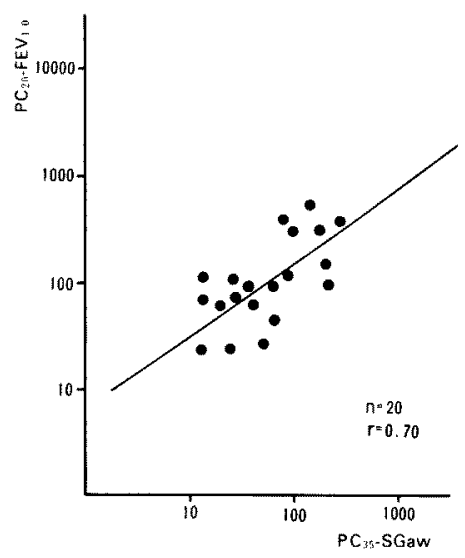

Fig 1. Comparison of $\mathrm{PC}_{20}-\mathrm{FEV}_{1,0}$ and $\mathrm{PC}_{35}-\mathrm{SGaw}$ in 20 asthmatics. The histamine $\mathrm{PC}_{20}-\mathrm{FEV}_{1.0}$ is on the vertical axis and the histamine $\mathrm{PC}_{35}-\mathrm{SGaw}$ is on the horizontal axis. Logarithmic scales are used. The line is the linear regression $(r=0.70$, slope $=$ $0.67)$.

Fig 1は, $\mathrm{PC}_{35}-\mathrm{SGaw}_{2} \mathrm{PC}_{20}-\mathrm{FEV}_{1.0}$ の関係を示し ているが, $\mathrm{Y}=0.85+0.67 \mathrm{X}, \mathrm{r}=0.70$ となり，よい 相関を示している. Fig 2は, $\mathrm{PC}_{35}-\mathrm{SGaw} と \mathrm{Cmin}$ 


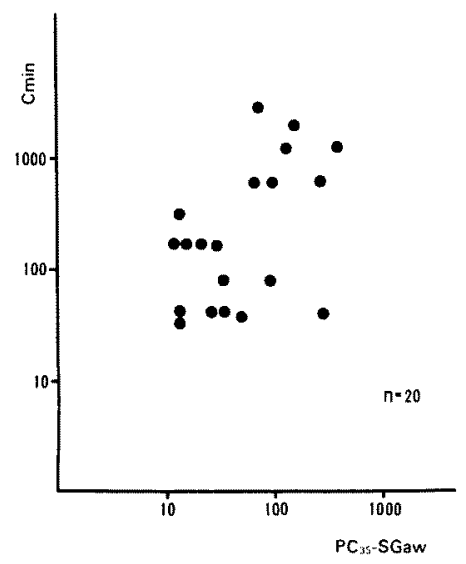

Fig 2. Comparison of $\mathrm{Cmin}$ and $\mathrm{PC}_{35}$-SGaw in 20 asth. matics.

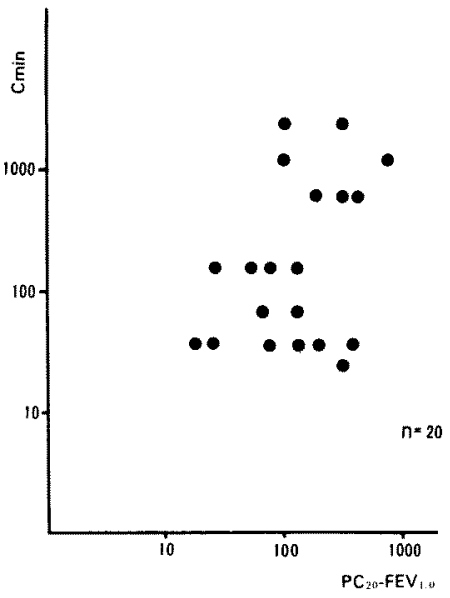

Fig 3. Comparison of $\mathrm{Cmin}$ and $\mathrm{PC}_{20} \cdot \mathrm{FEV}_{1, \mathrm{a}}$ in 20 asth. matics.

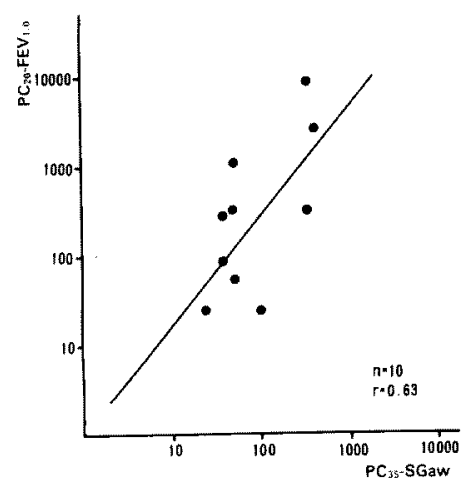

Fig 4. Comparison of $\mathrm{PC}_{20}$ $\mathrm{FEV}_{1.0}$ and $\mathrm{PC}_{35}$-SGaw in 10 patients with chronic pulmonar. y emphysema. The histamine $\mathrm{PC}_{20}-\mathrm{FEV}_{1.0}$ is on the vertical axis and the histamine $P_{35}$. SGaw is on the horizontal axis. Logarithmic scales are used. The line is the linear regression $(\mathrm{r}=0.63$, slope $=1.24)$.

Cminの関係を示し $(\mathrm{r}=0.50)$, Fig 1 のようなよい 相関は示していない。

次に，同様にして，慢性肺気腫群で，各方法に よる閥値の関係を示すと，Fig 4, Fig 5, Fig 6と なつた. Fig 4で $\mathrm{PC}_{35}-\mathrm{SGaw}$ と $\mathrm{PC}_{20}-\mathrm{FEV}_{1.0}$ は $\mathrm{r}=$ 0.63とよい相関を示している。な打Fig 5では， $\mathrm{PC}_{35}$-SGawとCminの関係を示し $(\mathrm{r}=0.10)$, Fig 6は, $\mathrm{PC}_{20}-\mathrm{FEV}_{1.0}$ とCminの関係を示している $(\mathrm{r}=$ 0.50).よつて, $\mathrm{PC}_{35}$-SGawとCminの相関はとく に悪かつた。

気管支喘息群23例でのbody box法で測定した $\mathrm{PC}_{35}$-SGaw (sensitivity) とdose-response curve の傾きの絶対值（reactivity）の関係をFig 7に示 した. $\mathrm{r}=0.26$ と，両者間の相関は認めなかつた。

同様に慢性肺気腫群10例でのbody box法での sensitivityと reactivityの関係をFig 8に示した. $\mathrm{r}=0.02$ となり，両者間の相関は全く認めなかつ た.

次に，気管支喘息群23例，慢性肺気腫群10例の， body box法に打けるsensitivity と reactivityの平 均值をそれぞれ示した（Table 2). sensitivityは， 気管支喘息群で $1,73 \pm 0.10$, 慢性肺気腫群で $1.81 \pm 0.21$ であり，前者が低值を示しているが， 平均值の差の検定を行ならと, 統計的には有意差

Table 2. Relation of sensitivity and reactivity in bronchial asthma and chronic pulmonary emphysema. Sensitivity is measured via $\mathrm{PC}_{35}-\mathrm{SGaw}$, and reactivity is defined as the slope of the dose response curve.

\begin{tabular}{|c|c|c|c|}
\hline Sensitivity & $\begin{array}{c}\text { bronchial } \\
\text { asthma }\end{array}$ & $\begin{array}{c}\text { chronic } \\
\text { pulmonary } \\
\text { emphysema }\end{array}$ & $P$ \\
\hline $\begin{array}{l}n=23 \\
\text { Reactivity }\end{array}$ & $\begin{array}{c}1.81 \pm 0.21 \\
n=10\end{array}$ & NS \\
\hline$n=23$ & $\begin{array}{c}44.2 \pm 8.7 \\
n=10\end{array}$ & $P<0.01$ \\
\hline
\end{tabular}

を認めなかつた。これに対して，reactivityは，気 管支喘息群で81.9土4.7であり，慢性肺気腫群の $44.2 \pm 8.7$ に比して有意の高值を示した。慢性肺気 腫患者のsensitivityは，気管支喘息患者と同様に 低値を示すが，reactivityは，気管支喘息患者に比 して低かつた。

\section{IV. 考案}

気道過敏性研究の歷史は, 1921年に, Alexander 


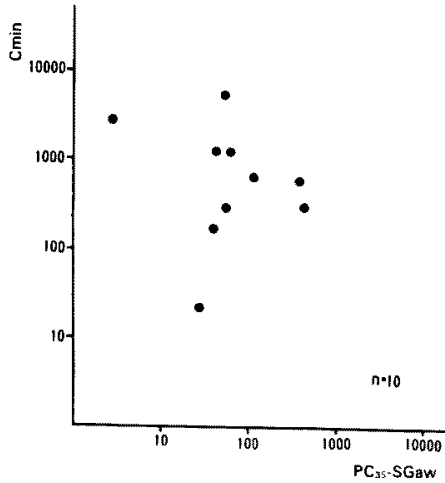

Fig 5. Comparison of $\mathrm{Cmin}$ and $\mathrm{PC}_{35}$.SGaw in 10 patients with chronic pulmonary emphysema.

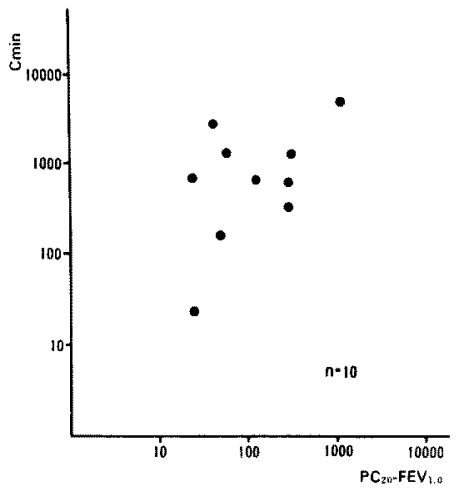

Fig 6. Comparison of $\mathrm{Cmin}$ and $\mathrm{PC}_{20}-\mathrm{FEV}_{1.0}$ in 10 patients with chronic pulmonary em. physema.
が，気管支喘息患者にピロカルピンを皮注したと ころ喘息呼吸をみたことに始まる4)、それ以来， 種々の吸入試験がなされてきた，各方法によつて 測定値が異なるので，測定值に影響を与える囚子 について, 種々の指摘がされている5．我々の教室 でも，薬物を吸入するネブライザー，呼吸の方法， 闌値を決める指標などにもとづくことを具体例を あげて報告している4).

吸入流量は，ネブライザーの種類によつて異な る.我々の施行した 3 法のらち, body box法と, スパイログラフィー法は, Devilbiss Model 646 Nebulizerを使用，吸入時間は 2 分間である。一 方アアストグラフ法は, Bird Nebulizerで, 1 分 間毎に吸入濃度が自動的に変わる連続乎吸法であ る.これは, $\mathrm{PC}_{35}-\mathrm{SGaw} と \mathrm{PC}_{20}-\mathrm{FEV}_{1,0}$ の相関がよ い(r=0.70)のに比べ，Cminとの相関が悪い一因 であらら。

そこで，我々は，同一気管支喘息患者 7 例に， アストグラフで, 各濃度のヒスタミンを他の 2 法 と同様に 2 分間吸入後，1秒量を測定した。 1 秒 量が基準值の $20 \%$ 低下した時のヒスタミン濃度 を, sensitivity $\left(\mathrm{PC}_{20}-\mathrm{FEV}_{1.0}\right.$, Bird Nebulizer $)$ とした。これをスパイログラフィー法の sensitivity $\left(\mathrm{PC}_{20}-\mathrm{FEV}_{1.0}\right.$, Devilbiss Model 646 Nebulizer)と比較した。同一文管支喘息恚者 7 例 で，两者の平均は，それぞれ， $\mathrm{PC}_{20} \cdot \mathrm{FEV}_{1.0}, \mathrm{Bird}$

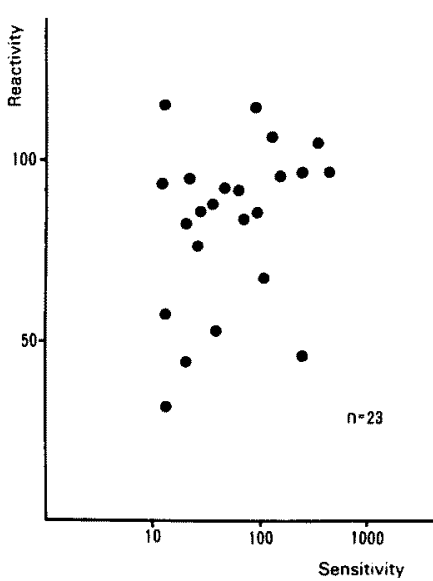

Fig 7. Relation of sensitivity and reactivity in 23 asthmatics. Sensitivity $\left(\mathrm{PC}_{35}-\mathrm{SGaw}\right)$ is on the horizontal axis. Logarithmic scales are used. Reactivity (the slope of individual doseresponse regression line) is on the vertical axis.

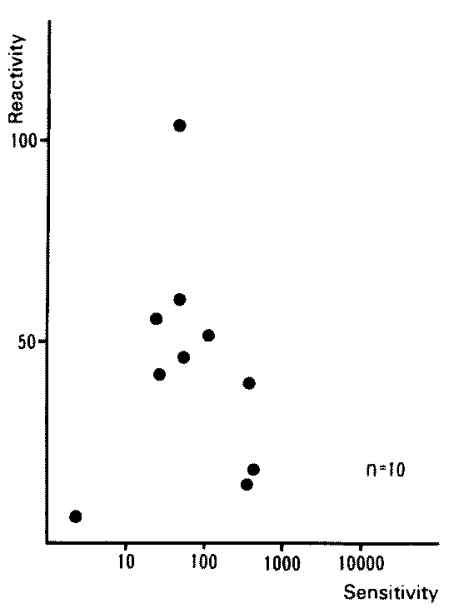

Fig 8. Relation of sensitivity and reactivity in 10 patients with chronic pulmonary emphysema.

Nebulizer $=2.22 \pm 0.16[$ mean $\pm \mathrm{SEM}], \mathrm{PC}_{20}$ $\mathrm{FEV}_{1.0}$, Devilbiss Model 646 Nebulizer $=2.17 \pm$ 0.16 [mean $\pm \mathrm{SEM}]$ で, 両者の相関は $\mathrm{r}=0.69$ と なつた，従つて，ネブライザーのみ变えて，同 一条件下で, $\mathrm{PC}_{20}-\mathrm{FEV}_{1.0}$ を測定寸ると相関がよい ことがわからた。

呼吸方法も測定因子に影響を与克る。すなかち， 
呼吸が大きいほど，また停止時間が長いほど粒子 の沈着が多く，鋭敏な值が得られる6) スパイログ ラムによる測定では，肺気管支の伸縮による刺激 だけで，気管支喘息患者の約 3 分の 1 K，多少と も発作が起こる7゙. 気管支喘息患者では, 1 秒量測 定時に，最大吸気をすること自体が気道抵抗 （Raw）に影響するし，1秒量の測定にも影響す る819). とくに慢性肺気腫患者では, 最大吸気, 努 力呼気という操作のくり返しが測定值に影響する と考えられる. body box法では, pantingという特 殊な呼吸法のため測定値が左右されやすい. pantingの速さによつて, 全肺気量 (TLC), 気道抵抗 (Raw)が変化するからである ${ }^{1011)}$. アストグラフ 法では, 安静呼吸下で, 呼吸インピーダンスを連 続的に测定できるので，検查時間も短く，患者へ の負担は少ない，乙かし，乎吸困難や，胗，体動 により, 測定值が大きく变動し, 解析困難な例も 多い.

吸入薬物については，アセチルコリン、ヒスタ ミンが一般に使用される。気管支喘息患者では, アセチルコリンとヒスタミンの閾值はr=0.70と よい相関を示すと報告されている ${ }^{12)}$. た, ヒスタ ミンとメサコリンに対する反応山再現性に富み, $\mathrm{PC}_{20}-\mathrm{FEV}_{1.0}$ (ヒスタミン) と $\mathrm{PC}_{20}-\mathrm{FEV}_{1.0}$ (メサ コリン)はよく相関することも報告されている $(\mathrm{r}=0.92)^{13)}$

我々の今回の成績では, body box法とスパイロ グラフィー法では，ネブライザー执よび吸入時間 が同一であり，フストグラフ法では異なる点もあ るが, $\mathrm{PC}_{35}-\mathrm{SGaw} と \mathrm{PC}_{20}-\mathrm{FEV}_{1.0}$ はよい相関を示

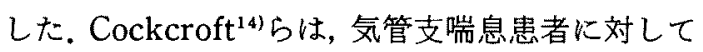
Wright Nebulizerを用いて, $0.03 \sim 0.08 \mathrm{mg} / \mathrm{ml}$ ヒスタミンを 2 分間吸入させ, $\mathrm{PC}_{35}-\mathrm{SGaw}$ と $\mathrm{PC}_{20} \cdot \mathrm{FEV}_{1.0}$ を測定し，両者はr $=0.86$ とい相関 を示すと報告した。さらに，健常人や軽度ないし 中等度の気管支喘息患者では, $\mathrm{PC}_{35}$-SGawが $\mathrm{PC}_{20}-\mathrm{FEV}_{1.0}$ より低值をとるとした。我々の結果で も, $\mathrm{PC}_{35}$-SGawの平均值は 3 法のうち最も低值を とつた。市た, Fig 1で20例中17例す $\mathrm{PC}_{35}$-SGawが $\mathrm{PC}_{20}-\mathrm{FEV}_{1.0}$ より低值を示した。従つて, 安静呼吸
での検査にもかかわらず患者は低濃度の吸入で陽 性となるので，吸入試験による副作用(呼吸困難, 咳，頭痛等）が軽いうちに検查を中止できる。

Body box法は, 検查所要時間が長く, 装置が複 雑で, 容易に施行できない点があるが, 安静呼吸 で検查でき, sensitivity と reactivityの分離解析が 可能である. また, SGawの算定に当り，気道抵抗 の逆数を残気量で除すことにより，気道卛縮に基 らく空気とらえこみ現象 (air trapping)のために 機能的残気量 (FRC) が增加して気道径が搪張す るという因子を補正できるなど，正確な閾值を把 握できる利点がある。しかし，ルチン検査である スパイログラフィー法と相関係数が高いことが確 認されたので，䦭値を測る臨床目的であれば，ス パイログラフィー法で十分とい点よう。

慢性肺気腫患者の気道過敏性についての報告は これまでほとんどなかつた。1971年, 教室の佐竹 は，喘息発作をもたない慢性肺気腫患者14例で， ヒスタミン吸入試験（日商式ネブライザー）に上 り, $200 \mu \mathrm{g} / \mathrm{ml}$ 以下の閾值 (中等度から高度) 例が $57 \%$ と報告した ${ }^{15) 16)}$. 一方慢性気管支炎単独群で は $10 \%$ 前後であつた ${ }^{15)}$ さらに，気管支喘息患者 を, 気管支喘息単独群, 慢性気管支炎合併群, 慢 性肺気腫群（兼慢性気管支炎）に分けて検討する と, $200 \mu \mathrm{g} / \mathrm{ml}$ 以下の閾値例はそれぞれ $63 \%, 71 \%$, $83 \%$ 示し，慢性気管支炎，慢性肺気腫が合併す るにつれ，気道過敏性が増加するとした ${ }^{16)}$.今回の 我々の成績では，気管支喘息を合併しない慢性肺 気腫群は、スパイログラフィー法 (Devilbiss Model 646 Nebulizer) による閾値の $156 \mu \mathrm{g} / \mathrm{ml}$ 下の例は $50 \%$ となり, 一方, 慢性肺気腫を合併し ない気管支喘息群では, $156 \mu \mathrm{g} / \mathrm{ml}$ 以下の閵值であ る例が71\%をしめた。 また，それぞれの閏值の平 均値は, body box法では, 慢性肺気腫群で1.81土 $0.21(n=10)$, 気管支喘息群で $1.73 \pm 0.10(n=23)$ であり，両者間に統計的有意差はなかつた。よつ て慢性肺気腫のsensitivity 高い例が多く, sensitivityだけでは，慢性肺気腫と気管支喘息を区別

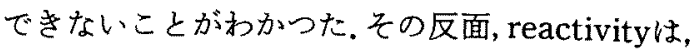
慢性肺気腫群では44.2 $28.7(n=10)$, 気管支喘息 


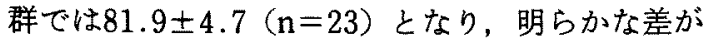
生じていることがわかつた。

標準法の基準に，検查前の 1 秒量が70\%以上が 望ましいという項目があり，一般的には，慢性肺 気腫患者で吸入試験を施行する例は少ない，1秒 量の20\%低下を閶値 $\left(\mathrm{PC}_{20}-\mathrm{FEV}_{1.0}\right)$ とすると， 1 秒量自体が少ないので, 少量の 1 秒量の変化で も\%低下は大さくなり，低い閾値の原因となろう。 しかし，今回，body box法での成績も含め，慢性 肺気腫患者で気道過敏性が高い例が多いといら結 果を得たので，今後さらに他の方法による場合も 含め例数を集めて検討してゆきたい.

Orehek ${ }^{177}$ は, ボリュームタイプのボディプレチ スモグラフを使い，スパイロの中に入れたカルバ コールのエフゾルを $860 \mathrm{ml}$ 吸入し， 4 秒間呼吸停 止した条件下で，SGawを測定した。 SGawが25\% 减少する点 $\left(\mathrm{D}_{25}\right)$ と, $60 \%$ 減少する点 $\left(\mathrm{D}_{60}\right)$ を結 び, この直線の傾斜を reactivity, $\mathrm{D}_{25}$ をsensitivity とした，健常者と気管支喘息群を比較すると，気 管支喘息群ではsensitivityが低く, reactivityが高 いそして、reactivityの方がより差が大きいとし た。またそそれそれれdose-response curveは平行 せず, sensitivityの亢進と reactivityの亢進が一致 しない例があると報告した。

1978年, 佐々林18)らは,メサコリンを, バポネフ

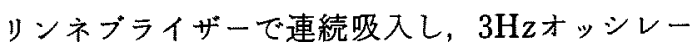
ション法の応用にて，呼吸抵抗を連続的に記録し た。初期抵抗（Rrs cont）から，呼吸抵抗の上昇 乙始める点までの累積投与量をDminとし，Dmin 上り2 分間吸入後の抵抗増加分と, その間の投与 量より求めたSdを解析し, Dminを sensitivity, Sd をreactivityとした，Rrs contとsensitivityとは $\mathrm{r}=-0.37$ で相関なく, reactivityとはr $=0.55 て ゙$ 弱 い相関が認められた。 Rrs contが正常例のみの場 合はsensitivity とreactivityはr $=-0.89$ とよい逆 相関を示したとしている. Orehekの解析では, 濃 度系列が常用対数表示でなく，一般的なdoseresponse curveの解析法と異なつている. 佐々木 らの方法によるSdは投与量で除した值であり，実 際には投与量が大さくなる汪どSd値は小さくな
るので, 必然的に, sensitivityと reactivityの相関 がよくなつてしまうことになる。1981年に至り， 滝島ら ${ }^{19}$ は，アストグラフ法で，呼吸抵抗の逆数 （Grs）を指標とし，Grsが初期值より低下した点の 累積濃度をDmin (sensitivity)とし, Grsの低下率 ( $\Delta \mathrm{Grs} / \mathrm{min}$ ) reactivityとした. sensitivityと reactivityは気管支喘息群で相関しないと報告し た。また，初期Grsと reactivityは，気管支喘息患 者に扔いて相関がよいと報告した。

アストグラフ法では, 気道過敏性の指標として, 1秒量の代わりに呼吸抵抗を用いている。我々の 方法では，3Hz固定で測定しているので呼吸イン ピーダンスと表現した。呼吸抵抗には気道抵抗の みならず肺組織抵抗も含まれる。よつて呼吸抵抗 の逆数 (Grs) は，コンダクタンスではなく，気道 抵抗の増加に伴う肺気量の増加を補正しない点 で，Grsを指標とすることにも問題があろう.

Sensitivity と reactivityといら概念が, Orehek ${ }^{17)}$ 以来用いられるが，我々の解析法では， sensitivityと reactivityは完全に分離したすので はない.つまり, sensitivity $\left(\mathrm{PC}_{35}\right.$-SGaw) は, SGawの減少し始めた点の濃度ではなく, 35\%减 少した点の吸入濃度を示しており，これはdoseresponse curveの傾き，つまり reactivityによつて 影響をらける。同様のことが, $\mathrm{PC}_{20}-\mathrm{FEV}_{1.0}$ につい てもいえる，この点で， Cminは呼吸インピーダン スの上昇し始める点の吸入濃度を示すので， reactivityに影響されない。しかし，アストグラフ 法では反応曲線が曲線的に上昇するため，傾斜を 正確に測定できないことにも問題点が残る。

Beaupré ${ }^{20)}$ は, ヒスタミン吸入試験で, $\mathrm{PC}_{20}$. $\mathrm{FEV}_{1.0}$ を sensitivity, dose-response curveの傾き の絶対值を reactivityとし, sensitivityの方が気管 支喘息患者の臨床状態をよく反映すると報告し た。

今回の我々の結果では, body box法でのsensitivity と reactivityは，気管支喘息，慢性肺気腫の 両疾患で相関がなかつた。そして，気管支喘息群 と慢性肺気腫群の間では, sensitivityには統計的 有意差はないが, reactivityには差があつた。この 
一因として，慢性肺気腫が，肺胞壁の破壊，気管 支平滑筋の萎縮性変化により, 収縮力が落ちてい ることも考觉らる。

さて, sensitivity と reactivityの概念は, 測定法, 解析法の統一をみないのが現状であるが，気管支 喘息の診断を病態の解明のために今後さらに研究 が進み，臨床応用されることが望ましい。

\section{V. 結 論}

気管支喘息患者（延23例）之慢性肺気腫患者（延 12例）に対し，できる限り同一条件で，ヒスタミ ン吸入試験をbody box法，スパイログラフィー (1 秒量)法, アストグラフ法で施行し, 成績を比 較した。

(1) Sensitivity(ヒスタミン吸入閏值)は，両疾 患群ともbody box法 ( $\mathrm{PC}_{35}$ - $\left.\mathrm{SGaw}\right)$, スパイログ ラフィー法 $\left(\mathrm{PC}_{20}-\mathrm{FEV}_{1,0}\right)$, アストグラフ法 (Cmin) の順に鋭敏であつた. body box法とスパ イログラフィー法の結果はよく一致したが，アス トグラフ法との一致率は低かつた。一方, body box法は強制呼気下で行ならスパイログラフィー 法（1秒量）に比し, 理論解析上すぐれた方法と 考光られた。

（2）Body box法に基づく，両疾患群でのsensitivity と reactivityの相関係数はともに低かつ た。一方，慢性肺気腫患者群では，気管支喘息患 者群とsensitivityには有意差を認めず，気道過敏 性の高い例が多かつた，反面，気管支喘息患者群 に比して reactivityが低值の例が多いこともわか つた。

\section{文献}

1）牧野荘平，他：気管支喘息㧍よび過敏泩肺臓炎に おける吸入試験の標染法、アレルギー $31: 1074$, 1982.

2）滝島 任, 他：気道過敏性検出のための新しい試 み。日本医事新報 $2797: 30,1977$.

3) American Thoracic Society Committee on Diagnostic Standards for Non-tuberculous Disease. Definitions and classification of chronic bronchitis, asthma, and pulmonary emphysema. Amer Rev Respir Dis 85 : 762, 1962.

4) 佐竹辰夫, 他：気道過敏性 (sensitivity と reacti- vity)とくに測定の問題点と臨床的意義. 綜合臨林 $32: 335,1983$.

5) Simonsson BG (山川育夫抄票)：気管支喘息に打 ける気道のHyperreactivityと関連する諸問題。呼 吸之㡒環 $28: 575,1980$.

6) Palmes ED: Effect of depth of inhalation on aerosol persistanse during breath holding. J Appl Physiol 34: 356, 1973.

7）佐竹辰夫，他：頑固な病歴をもつ閉塞性肺疾患， とくに気管支喘息に対する気管支桩張剤isoprophenamineの使用経験（吸入効果拉よび長期内 服). 猃療 $21: 1171,1968$.

8) Orehek J, et al: Influence of the previous deep inspiration on the spirometric measurement of provoked bronchoconstriction in asthma. Amer Rev Respir Dis $123: 269,1981$.

9) Orehek J, et al : Effect of maximal respiratory maneuvers on bronchial sensitivity of asthmatic patients as compared to normal people. Brit Med J 1: 123, 1975.

10) Shore SA, et al: Effect of panting frequency on the plethysmographic determination of thoracic gas volume in chronic obstructive pulmonary disease. Amer Rev Respir Dis 128: 54, 1983.

11）佐藤洋子, 他：ボディープレチスモグラフィーに 上る気道抵抗の測定。蓜生検查 $30: 605,1981$.

12) Makino S: Clinical significance of bronchial sensitivity to acetylcholine and histamine in bronchial asthma. J Allergy 38: 127, 1966.

13) Juniper EF, et al: Reproducibility and comparison of responses to inhaled histamine and methacholine. Thorax $33: 705,1978$.

14) Cockcroft DW, et al: Measurement of responsiveness to inhaled histamine : Comparison of $\mathrm{FEV}_{1}$ and SGaw. Ann Allergy $51: 374,1983$.

15）佐竹辰夫，他：慢性閉塞性肺疾患(僈性気管支炎, 慢性肺気腫，気管支喘息）に战ける鑑別診断の意 義と実際。日本胸部臨床 $30: 511,1971$.

16）佐竹辰夫：閉塞性肺疾患（慢性気管支炎之肺気 腫). 新内科学大系, $28 \mathrm{C}$, 呼吸器知患 IIIC, 中山 書店, 東京, 1978, p3.

17) Orehek J, et al: Airway response to carbacol in normal and asthmatic subjects. Amer Rev Respir Dis 115 : 937, 1977.

18）佐々木孝夫：気道刺激剤吸入負荷試験。日胸疾会 誌 $16: 552,1978$.

19) Takishima $T$, et al: Direct-writing recorder of the dose-response curves of the airway to methacholine. Chest $80: 5,1981$.

20) Beauprê A, Malo JL: Histamine doseresponse curves in asthma: relevance of the distinction between $\mathrm{PC}_{20}$ and reactivity in characterising clinical state. Thorax $36: 31,1981$. 